\title{
Molecular Evidence for Association of Tobacco Curly Shoot Virus and a Betasatellite with Curly Shoot Disease of Common Bean (Phaseolus vulgaris L.) from India
}

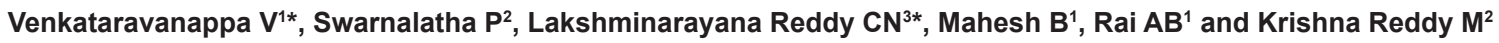 \\ ${ }^{1}$ Division of Crop Protection, Indian Institute of Vegetable Research, Varanasi-221305, Uttar Pradesh, India \\ 2Indian Institute of Horticultural Research, Hessaraghatta Lake PO, Bangalore-560089, Karnataka, India \\ ${ }^{3}$ Department of Plant Pathology, College of Sericulture, University of Agricultural Sciences (B), Chintamani-563125, Karnataka, India
}

\begin{abstract}
A new strain (FB01) of Tobacco curly shoot virus (TbCSV) showing curly shoot symptoms on common bean plants from Varanasi, Uttar Pradesh state of India was characterized. The analysis of the whole genome sequence and individual ORFs of this virus indicated that it is very closely related (sequence similarity of $89.1-94.5 \%$ ) to the TbCSV infecting solanaceous and other weed crops in India and China. This was well supported by phylogenetic analysis with close clustering of the virus isolate with TbCSV. The absence of DNA-B and association of virus with betasatellite confirmed it as a monopartite begomovirus. The betasatellite identified here shared highest (53.9$93.9 \%$ ) sequence identity with tomato leaf curl betasatellite. Further, putative recombination events were recognized within the virus sequence, suggesting that the virus is a recombinant and evolved from recombination of Tobacco curly shoot virus, Munbean yellow mosaic virus, Tomato leaf curl Jodhpur virus, Tobacco leaf curl Yunnan virus and Ageratum enation virus like ancestors. For betasatellite, the putative recombination events were recognized within the sequence, were interspecific. The new recombinant betasatellite was derived from recombination between Croton yellow vein mosaic betasatellite and Tomato yellow leaf curl China betasatellite, as the foremost parents in its evolution. The virus was transmitted by whiteflies as well as sap, and not by seed.
\end{abstract}

Keywords: Common bean; Tobacco curly shoot virus (TbCSV); Tomato leaf curl betasatellite (ToLCB); PCR; Whitefly; Phylogentic analyses; Recombination

\section{Introduction}

The begomoviruses belong to the family Geminiviridae, are apparently evolving as rapidly as some RNA viruses [1]. The Geminiviruses are divided into four genera, namely Mastrevirus, Curtovirus, Topocuvirus and Begomovirus, on the basis of virus insect vectors, host range and genome organization. The Begomovirus is the largest genus of this family and comprises whitefly transmitted geminiviruses, infecting dicotyledonous plants [2]. The genomes of Begomoviruses consist of single component (Monopartite) or two components (Bipartite), which are having approximate size of $2.6-2.8 \mathrm{~kb}$ each. The DNA-A in bipartite viruses and its homolog in monopartite viruses encodes pre-coat protein and coat protein in the sense strand, which are essential for transmission [3], and Replication-associated protein (Rep); the Replication Enhancer protein (REn) required for viral DNA replication; the Transcriptional Activator Protein (TrAP) required for gene expression control in the complementary strand. DNA-B encodes proteins required for intracellular movement (BC1, BV1) and transport of viral ssDNA in the host plant $[4,5]$. The two components share a region of high sequence homology that is known as CR, the place from where the replication of the viral DNA genomes initiates.

Most of the Begomoviruses originating from the Old World has been shown to be monopartite and known to associate with a class of ssDNA satellites, known as betasatellites and aphasatellites. Betasatellites are approximately half the size of their helper Begomoviruses, required to induce typical disease symptoms in their original hosts $[6,7]$. These satellites depend on their helper virus for replication, movement, encapsidation and vector transmission. Alphasatellites are self replicating (Autonomous) circular ssDNA molecule, and are evolved from nanoviruses (Nanoviridae; family of circular ssDNA viruses) that became associated with Begomoviruses during mixed infections [8]. Alpha-satellites depend on the helper virus for movement, encapsidation and vector transmission, and play no role in symptom induction $[6,7,9,10]$.

Grain legume crops across southern Asia suffer huge losses due to disease caused by Begomoviruses [11]. In southern Asia, four distinct begomoviruses associated with grain legumes are Mungbean yellow mosaic virus, Mungbean yellow mosaic India virus [12-15], Horsegram yellow mosaic virus [16] and Dolichos yellow mosaic virus [17]. They affect all major legume crops, including mungbean (Vigna radiata), blackgram (Vigna mungo), pigeonpea (Cajanus cajan), soybean (Glycine max), mothbean (Vigna aconitifolia), and common bean (Phaseolus vulgaris) [18].

The genus Phaseolus has over 50 species, and rajma or common bean (Phaseolus vulgaris L.) is one of them, accounting for $90 \%$ of cultivated

*Corresponding authors: Venkataravanappa V, Division of Crop Protection, Indian Institute Vegetable Research, Varanasi-221305, Uttar Pradesh, India, Fax: (05443)-229007; E-mail: venkatrajani@gmail.com

Lakshminarayana Reddy CN, Department of Plant Pathology, College of Sericulture, University of Agricultural Sciences (B), Chintamani-563125, Karnataka, India, E-mail: cnlreddy@gmail.com

Received October 12, 2012; Accepted November 23, 2012; Published November 28, 2012

Citation: Venkataravanappa V, Swarnalatha $\mathrm{P}$, Lakshminarayana Reddy $\mathrm{CN}$ Mahesh B, Rai AB, et al. (2012) Molecular Evidence for Association of Tobacco Curly Shoot Virus and a Betasatellite with Curly Shoot Disease of Common Bean (Phaseolus vulgaris L.) from India. J Plant Pathol Microb 3:148. doi:10.4172/21577471.1000148

Copyright: (c) 2012 Venkataravanappa V, et al. This is an open-access article distributed under the terms of the Creative Commons Attribution License, which permits unrestricted use, distribution, and reproduction in any medium, provided the original author and source are credited. 
Citation: Venkataravanappa V, Swarnalatha P, Lakshminarayana Reddy CN, Mahesh B, Rai AB, et al. (2012) Molecular Evidence for Association of Tobacco Curly Shoot Virus and a Betasatellite with Curly Shoot Disease of Common Bean (Phaseolus vulgaris L.) from India. J Plant Pathol Microb 3:148. doi:10.4172/2157-7471.1000148

Page 2 of 9

species throughout the world. Globally, common bean is cultivated on about 28 million hectares per annum with a production of 19 million tonnes. Brazil is the leading producer of common bean. In India, both bushy and trailing types of common bean are grown in different part of the country, which is a key component of the cropping system due to its seeds as an importance source of rich protein (23\%). Seeds are also rich in calcium, phosphorus and iron. The fresh pods and green leaves are used as vegetable in the diet, predominantly in vegetarian population of Uttar Pradesh state and eastern parts of India. The major limitation for cultivation of common bean (Phaseolus vulgaris L.) is Golden mosaic disease caused by whitefly-transmitted Geminivirus [11]. The random survey of different fields of common bean at Varanasi, India during 2010-2012 for incidence of viral diseases, revealed several farm fields of common bean showing predominantly, stunting, stem twisting, curly shoot, thickening of veins in the lower leaf surface and galling with dark green colour symptoms, along with whitefly Bemisia tabaci. These typical disease symptoms and occurrence of whitefly indicated the possibility of a Begomovirus infection. Therefore, the present study was taken up to characterize the new strain of Begomovirus associated with curly shoot disease of common bean in India.

\section{Materials and Methods}

\section{Virus source, virus transmission and its maintenance}

Leaf samples were collected from the common bean plants exhibiting stunting, stem twisting, curly shoot, thickening of lower leaf surface veins and galling with dark green colour symptoms, from the major common bean growing areas from Varanasi, Uttar Pradesh, India (Figure 1). From this infected leaf sample, the virus was transmitted to common bean cv. Arka komal using whitefly B. tabaci. In order to rule out the mixed infections to the least possible extent, repeated transmissions were carried out under controlled conditions and finally, the virus isolate was designated as-FB01 and used for all other studies. The culture of nonviruliferous whiteflies used for the transmission experiments were initially collected from egg plant (Solanum melongena L.), brought to the laboratory and allowed to feed and lay eggs on healthy cotton plants (Gossypium hirsutum L. cv. Laxmi) for sufficient period. After this, eggs were collected and virus-free stock of whiteflies was reared on healthy cotton plants in large wooden cages $(45 \times 45 \times 30 \mathrm{~cm})$, covered with insect proof cages galvanized with wire mesh (40-mesh size), and kept in the temperature $\left(30^{\circ} \mathrm{C}\right)$ and Relative Humidity $(\mathrm{RH})(60 \%)$ controlled glasshouse. Sample from non-symptomatic plant was also collected from the field.

\section{DNA isolation}

Total DNA was extracted from symptomatic and non-symptomatic plants maintained in glasshouse, and as well as field collected samples by Cetyl trimethyl ammonium bromide method [19]. The extracted DNA was diluted to required concentration with sterile distilled deionised

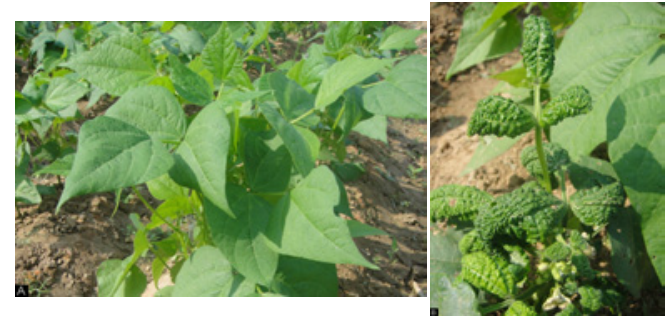

Figure 1: Healthy bean plant (A) and virus infected bean plant showing curly shoot symptoms (B), under natural conditions observed during the sample collection.

\begin{tabular}{|l|l|l|l|l|l|}
\hline ORFS & $\begin{array}{l}\text { Start codon } \\
\text { (nucleotide } \\
\text { coordinates) }\end{array}$ & $\begin{array}{l}\text { Stop codon } \\
\text { (nucleotide } \\
\text { coordinates) }\end{array}$ & $\begin{array}{l}\text { Predicted } \\
\text { size of } \\
\text { ORFs (nt) }\end{array}$ & $\begin{array}{l}\text { Predicted size } \\
\text { of protein } \\
\text { (no. of amino } \\
\text { acids) }\end{array}$ & $\begin{array}{l}\text { Predicted } \\
\text { Mr (kDa) }\end{array}$ \\
\hline AV1(CP)* & 294 & 1064 & 771 & 256 & 28.16 \\
\hline V2 & 134 & 490 & 357 & 118 & 12.98 \\
\hline Rep & 2598 & 1513 & 1086 & 361 & 39.71 \\
\hline TrAP & 1610 & 1206 & 405 & 134 & 14.74 \\
\hline REn & 1465 & 1061 & 405 & 134 & 14.74 \\
\hline C4 & 2441 & 2148 & 294 & 97 & 10.67 \\
\hline
\end{tabular}

*Genes are indicated as Coat Protein (CP), Replication-associated protein (Rep), Transcriptional Activator Protein (TrAP), and Replication Enhancer (REn). The products encoded by ORFs V2 and C4 have yet to be named.

Table 1: Features of the begomovirus isolated from common bean.

water, before being subjected to PCR amplification and stored at $-20^{\circ} \mathrm{C}$.

\section{PCR amplification, cloning and sequencing}

Complete genome of virus isolate was amplified by PCR, as described by Venkataravanappa et al. [20]. For the confirmation of second component (DNA- B) and betasatellite in the sample, the universal degenerate primers specific to DNA-B [20,21] and betasatellite [22] were used. Amplified PCR products were purified from agarose gels and cloned into the plasmid vector pTZ57R/T, using T/A cloning kit (Fermentas Life Sciences, USA), according to the manufactures instructions. The complete nucleotide sequence of clones from each sample (three clones for each sample were sequenced) were determined by automated DNA sequencer, ABI PRISM 3730 (Applied Biosystems) from Anshul Biotechnologies DNA Sequencing facility, Hyderabad, Andhra Pradesh, India.

\section{Comparison of DNA Sequences}

The sequences obtained were verified for the presence of all Begomovirus specific ORFs (using NCBI ORF finder) and conserved nonanucleotide sequence. The sequence results were analysed using NCBI (www.ncbi.nlm.nih.gov) blast search, followed by sequence analysis using Bioedit Sequence Alignment Editor (version 5.0.9) [23], to determine percentage sequence identity/similarity with other species, which showed maximum identity in the blast search (Supplementary table 1). Full-length genome of selected Begomovirus species and betasatellites were aligned using Cluastal W [24], and phylogenetic trees were generated by MEGA 5.0 software [25], using the neighbour joining method with 1000 bootstrapped replications, to estimate evolutionary distances between all pairs of sequences simultaneously.

\section{Detection of recombination events}

The phylogenic evidence for recombination was detected by alignment of selected Begomoviruses sequences reported from India, which are available in the database along with bean isolate using SplitsTree version 4.3 with neighbour-Net method [26]. The method depicts the conflicting phylogenetic signals caused by recombination as cycles, within unrooted bifurcating trees. Recombination break points analyses was carried out using Recombination Detection Program (RDP), GENECOV, Bootscan, Max Chi, Chimara, Si Scan, 3Seq integrated in RDP 3 [27]. Default RDP settings with $0.05 P$-value cut off throughout and standard Bonferroni correction were used.

\section{Virus transmission experiments}

Vector transmission: The virus transmission protocols were carried out similar to those described by Venkataravanappa et al. [20]. Time required for optimum virus acquisition, inoculation and incubation 
Citation: Venkataravanappa V, Swarnalatha P, Lakshminarayana Reddy CN, Mahesh B, Rai AB, et al. (2012) Molecular Evidence for Association of Tobacco Curly Shoot Virus and a Betasatellite with Curly Shoot Disease of Common Bean (Phaseolus vulgaris L.) from India. J Plant Pathol Microb 3:148. doi:10.4172/2157-7471.1000148

were determined by inoculating one week old healthy common bean $\mathrm{cv}$. Arka komal seedlings with the virus isolate. Minimum number of $B$. tabaci adults required to transmit TbCSV was also determined.

Mechanical transmission: The infected common bean leaves (cv Arka komal) were harvested 10 days after whitefly inoculation with the virus isolate and macerated in a pestle and mortar by adding ice cold $0.05 \mathrm{M}$ phosphate buffer, $\mathrm{pH} 7.5$ containing 1 percent of 2 -mercaptoethanol. The resultant pulp was squeezed between two folds of sterile absorbent cotton. Celite (6000 mesh) was added to the inoculum at $0.025 \mathrm{~g}$ per $\mathrm{ml}$ as abrasive, and one week old seedlings of common bean cv. Arka komal were inoculated by the unidirectional rubbing of forefinger dipped in inoculum. After 15 minutes, the excess inoculum was washed with a jet of water using the squeeze bottle. The plants were maintained in the separate compartment of the glasshouse for symptom production, which was free of insects. The experiment was repeated thrice and each time, 25 plants were inoculated.

Seed transmission: The matured seeds were collected from plants showing distinct curly shoot symptoms and non symptomatic healthy common bean cv. Arka komal. The seeds were treated with $2 \%(\mathrm{v} / \mathrm{v})$ sodium hypochlorite for $2 \mathrm{~min}$, rinsed with water several times. Three sets of 25 seeds, each from healthy and diseased plants were sown in soil, sand and compost $(2: 1: 2 \mathrm{w} / \mathrm{w})$ mixture in separate earthen pots. After recording germination percentage, the earthen pots with seedlings were kept in glasshouse for 1 month for symptoms development. The seedlings were sprayed with imidicloprid $(0.05 \%)$ at 10 days interval to avoid chances of insect transmission, and the presence of virus in the seedlings was confirmed by PCR.

\section{Results}

\section{Disease transmission by whitefly}

All whitefly inoculated common bean seedlings showed symptoms those observed on the field infected plants, after every repeated inoculations (sub culturing) to healthy plants. The transmission tests were highly successful as the infection rate was $100 \%$ on tested common bean susceptible seedlings (Figure 2). These samples were used along with the field samples for all further experiments.

\section{Genome amplification and sequencing}

The complete genome of the virus was amplified by using three sets of primers from field infected and glasshouse inoculated samples, and attempts to amplify DNA-B components were unsuccessful. However, the positive amplification of betasatellite component by PCR with a universal abutting primer pair beta0l/beta02 in both samples, confirmed that the Begomovirus infecting common bean (P. vulagaris) is monopartite. Samples from non-symptomatic plants
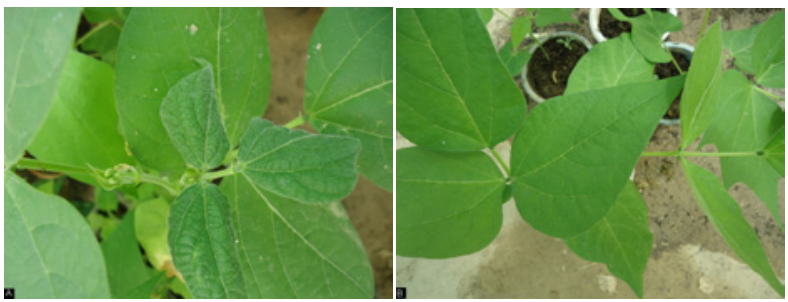

Figure 2: Common bean (cv. Arka komal) plant showing curly shoo symptoms (A), 17 days after whitefly (B. tabaci) inoculation with TbCSVFB01. Bean plant without symptoms (B) inoculated with whiteflies, given acquisition access on healthy plant used as negative control in the experiment to rule out the whitefly contamination with viruses.

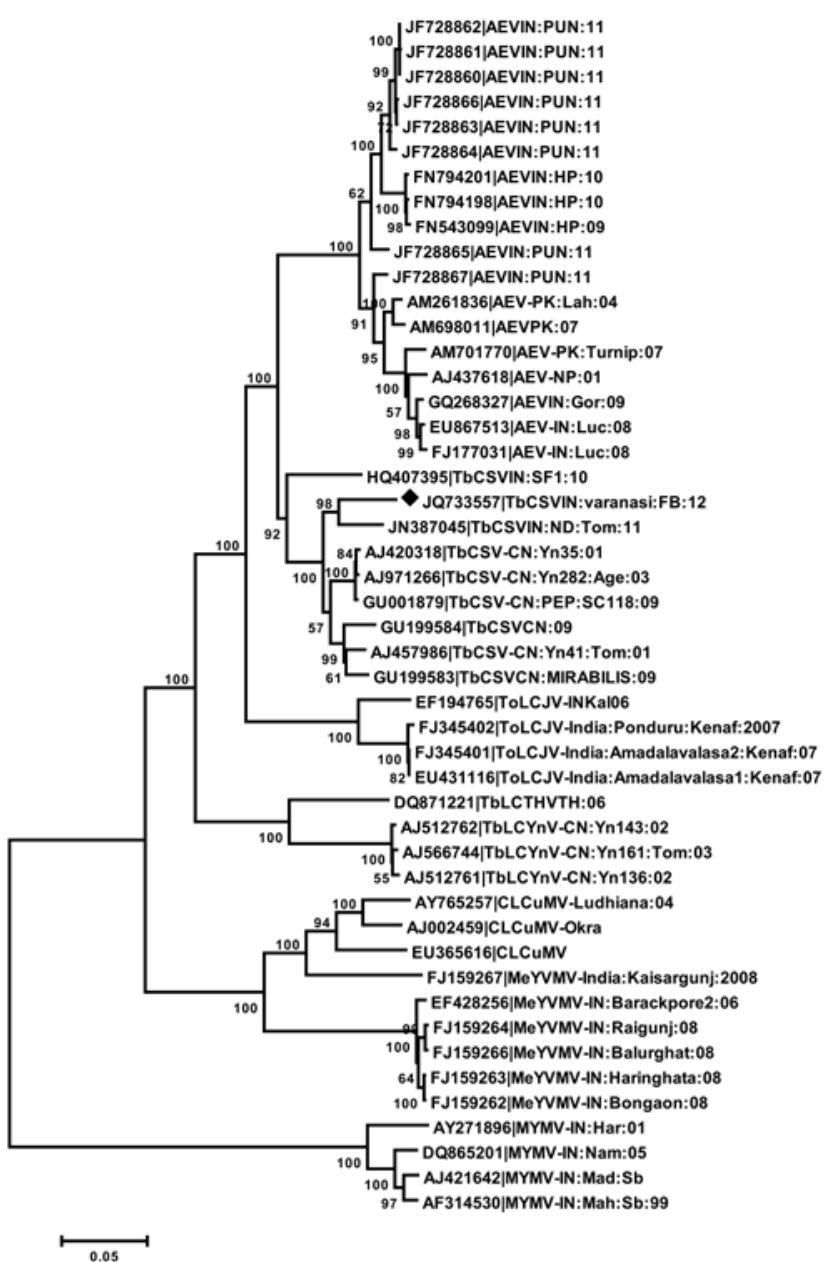

Figure 3: Phylogenetic trees constructed from aligned complete nucleotide sequence of genome component (homologous to DNA-A component of bipartite begomoviruses) of TbCSV-FB01 with other begomovirus sequences retrieved from NCBI (www.ncbi.nih.gov), using Neighbor-joining algorithm. Horizontal distances are proportional to sequence distances, vertical distances are arbitrary. The trees are unrooted. A bootstrap analysis with 1000 replicates was performed, and the bootstrap percent values more than 50 are numbered along branches.

and healthy plant from the glasshouse failed to amplify for all three genome components, and served as a negative control. The amplified fragments were cloned and three clones in each case were sequenced. The alignment of sequences from multiple clones of field sample as well as glasshouse sample were identical, and all further analyses were done with the representative sequence of the virus isolate-FB01.

\section{Genome organization, sequence and phylogenetic analysis}

The complete genome (homologous of DNA-A) of the virus isolate-FB01 infecting common bean was determined to be $2746 \mathrm{nts}$ (JQ733557). The genome organization is typical of other Old world monopartite Begomoviruses, comprising two Open Reading Frames (ORFs) [AV1 (CP), AV2] in virion-sense strand and four ORFs [AC1 (Rep), AC2, AC3, AC4] in complementary-sense strand, separated by an Intergenic Region (IR) (Table 1). Comparisons of this virus sequence with other reported Begomoviruses sequences revealed the present isolate infecting common bean have highest sequence identity (89.1-94.5\%) with Tobacco curly shoot virus (TbCSV), found in India and China infecting solanaceous and other weed crops, while it shares 
Citation: Venkataravanappa V, Swarnalatha P, Lakshminarayana Reddy CN, Mahesh B, Rai AB, et al. (2012) Molecular Evidence for Association of Tobacco Curly Shoot Virus and a Betasatellite with Curly Shoot Disease of Common Bean (Phaseolus vulgaris L.) from India. J Plant Pathol Microb 3:148. doi:10.4172/2157-7471.1000148

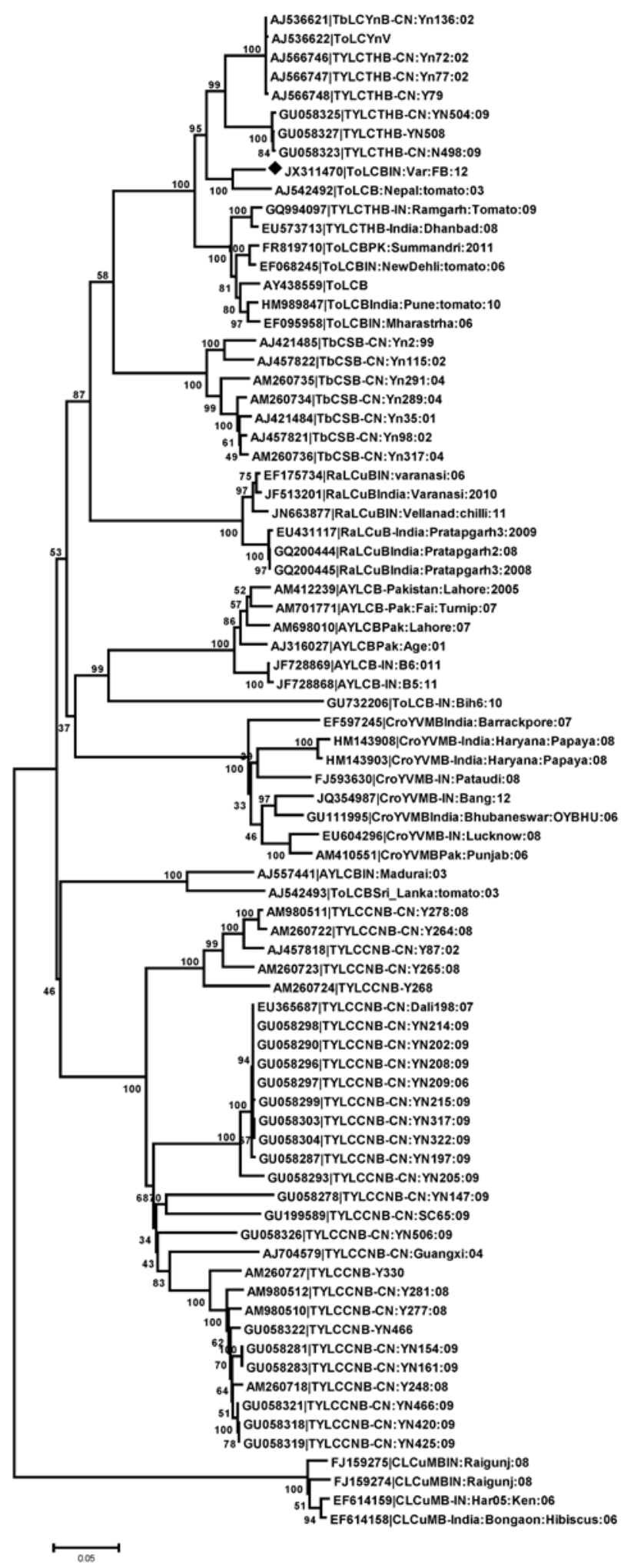

Figure 4: Phylogenetic trees constructed from aligned complete nucleotide sequence of betasatellite associated with TbCSV-FB01, with other betasatellite sequences retrieved from NCBI (www.ncbi.nih.gov) using Neighbor-joining algorithm. Horizontal distances are proportional to sequence distances, vertical distances are arbitrary. The trees are unrooted. A bootstrap analysis with 1000 replicates was performed, and the bootstrap percent values more than 50 are numbered along branches. less than $83 \%$ identity with rest of the Begomoviruses infecting pulses, tomato, tobacco, mesta and cotton. These results suggest that virus isolate-FB01 is an isolate of TbCSV (Table 2), based on the current criteria for classification of Begomoviruses [2]. This was well supported by a phylogenetic analysis showing close clustering of virus isolateFB01 with TbCSV infecting tomato in India, for which a full-length sequence is available in the databases (Figure 3 ).

Further, the percent amino acid identities of FB01 isolate with other Begomoviruses sequences revealed that the ORFAV2, AV1, AC1, $\mathrm{AC} 2, \mathrm{AC} 3$ and AC4 showed maximum identity with isolate of TbCSV infecting different crop plants with exception of ORF AC4, which is having maximum identity for both TbCSV and TbLCTHV (Table 2). The Intergenic Region (IR) is $~ 281 \mathrm{nts}$ in length, and is similar to that of TbCSV infecting tomato plants and shared sequence identities, ranged from $73.1-95.3 \%$ with TbCSV, and only 13.1-78.3\% with IRs of other Begomoviruses (Table 2). The IR contains a predicted stem-loop sequence with conserved nonanucleotide sequence (TAATATTAC) in the loop, which is found in the majority of the Geminiviruses characterized to date, and marks the origin of virion-strand DNA replication [28]. Within the intergenic region, incomplete two direct repeats (GGGTCC nt positions 2614-2619 and 2649-2654) of an iteron sequences were identified, adjacent to the TATA box of the Rep promoter and are probable Rep binding motifs, which binds in a sequence-specific fashion to iterated DNA motifs (iterons), functioning as essential elements for virus-specific replication.

\section{Genome organization of betasatellite and sequence affinities to other beta satellites}

The complete nucleotide sequence of betasatellite from virus isolateFB01 was determined to be $1352 \mathrm{bp}$ in length (JX311470). The sequence contain all the features of other betasatellites [7], a region of sequence rich in adenine, a single predicted gene in the complimentary sense $(\beta C 1)$, with the capacity to encode a 118 amino acids, with a predicted molecular weight of $12.98 \mathrm{kDa}$ and a region of sequence conserved across all betasatellites (known as the satellite conserved region). The satellite conserved region is approximately $142 \mathrm{bp}$ and contains at its 3 ' end, a predicted hairpin structure having a loop, with the sequence TAATATTAC, similar to the origin of replication of Geminiviruses.

Pair wise sequence comparisons with other closely related sequences in the databases (Supplementary table 2) suggested that the satellite showed highest level of identity (53.9-93.9\%) to the isolates of tomato leaf curl associated betasatellite (ToCLB), for which sequences are available in the database (Table 3 ). Based on the recently proposed species demarcation threshold of 78\% for betasatellites [29], the results suggest that betasatellite identified here is an isolate of ToCLB. This was well supported by a phylogenetic analyses showing close clustering of betasatellite, associated with TbSCV infecting common bean with ToCLB infecting tomato in Nepal, for which a full-length sequence is available in the databases (Figure 3).

\section{Recombination analysis}

The phenomenon of mixed infections between viruses causing yellow mosaic of bean, tomato and ageratum providing the prerequisite for the process, where natural recombination might have contributed to the emergence of novel begomoviruses [30,31]. Initially, neighbournet analysis was carried to detect the phylogenetic conflict by using sequences of Begomoviruses infecting pulses, tomato, tobacco, cotton and mesta, along with isolate (TbSCV) with Splits-Tree version 4.11.3 (Figure 4). Such networks are capable of graphically displaying patterns 
Citation: Venkataravanappa V, Swarnalatha P, Lakshminarayana Reddy CN, Mahesh B, Rai AB, et al. (2012) Molecular Evidence for Association of Tobacco Curly Shoot Virus and a Betasatellite with Curly Shoot Disease of Common Bean (Phaseolus vulgaris L.) from India. J Plant Pathol Microb 3:148. doi:10.4172/2157-7471.1000148

Page 5 of 9

\begin{tabular}{|c|c|c|c|c|c|c|c|c|}
\hline \multirow[t]{2}{*}{ Begomovirus\# } & \multirow[t]{2}{*}{ Genome } & \multirow[t]{2}{*}{ IR } & \multicolumn{6}{|c|}{ Gene (percentage amino acid sequence identity) } \\
\hline & & & AV2 & $\mathrm{CP}(\mathrm{AV} 1)$ & $\operatorname{Rep}(\mathrm{C} 1)$ & $\operatorname{TrAP}(\mathrm{C} 2)$ & REn (C3) & C4 \\
\hline $\operatorname{TbCSV}(8)^{*}$ & 89.1-94.5 & 73.1-95.3 & 92.3-96.6 & 96.0-98.8 & 77.3-91.4 & $91.7-94.0$ & $87.3-97.0$ & 61.4-89.6 \\
\hline TbLCYnV (3) & 78.1-78.3 & $69.2-70.3$ & $93.2-94.9$ & $80.0-81.2$ & $75.0-78.2$ & $61.9-62.9$ & $67.1-67.9$ & $41.2-42.2$ \\
\hline ToLCJV (4) & $83.2-83.0$ & $52.6-64.6$ & 38.7-86.7 & $94.9-95.7$ & $83.1-84.2$ & $77.6-78.3$ & 76.8-79.1 & $61.8-65.9$ \\
\hline AEV (18) & $85.0-86.3$ & 31.1-70.7 & $45.2-95.6$ & 96.8-97.6 & 76.5-79.3 & 81.1-88.8 & $86.5-9.25$ & $38.1-42.2$ \\
\hline CLCuMV (3) & 72.9-73.0 & 53.3-54.4 & $65.0-66.5$ & 90.6-91.4 & 74.4-76.0 & $62.6-64.0$ & 69.4-70.1 & $44.0-45.0$ \\
\hline MeYVMV (6) & 71.7-72.0 & $51.0-53.7$ & 64.4-67.7 & $79.2-90.6$ & 73.9-76.3 & $56.6-59.3$ & $60.2-67.9$ & $41.1-42.0$ \\
\hline MYMV (4) & 62.9-63.2 & 13.1-35.5 & $35.5-37.2$ & 73.9-75.0 & 70.5-71.5 & $41.0-42.5$ & $41.0-42.5$ & 47.4-55.5 \\
\hline TbLCTHV (1) & 83.1 & 78.3 & 92.3 & 81.2 & 90.0 & 62.9 & 67.9 & 89.6 \\
\hline
\end{tabular}

*Numbers of sequences from the databases used in the comparisons.

\#The species are indicated as Tobacco curly shoot virus (TbSCV), Tobacco leaf curl Yunnan virus (TbLCYnV), Tomato leaf curl Joydebpur virus (ToLCJV), Ageratum enation virus (AEV), Cotton leaf curl Multan virus (CLCuMV), Mesta yellow vein mosaic virus (MeYVMV), Mungbean yellow mosaic virus (MYMV), Tobacco leaf curl Thailand virus (TbLCTHV). For each column, the highest value is underlined.

Table 2: Pairwise comparisons of percent nucleotide identities between the genomic components and amino acid sequence identities of encoded genes of TbCSV-FB01, infecting common bean with selected begomoviruses from the databases.

\begin{tabular}{|l|l|l|}
\hline Begomoviruses & $\begin{array}{l}\text { Complete sequence of } \\
\text { DNA } \boldsymbol{\beta} \text { (percentage NSI) }\end{array}$ & $\begin{array}{l}\text { Percentage amino acid sequence } \\
\text { identity of } \boldsymbol{\beta C 1} \text { gene }\end{array}$ \\
\hline ToLCB $(7)^{*}$ & $53.9-93.9$ & $57.6-96.6$ \\
\hline TbCSB (7) & $73.2-74.1$ & $61.0-64.4$ \\
\hline TYLCTHB (10) & $84.9-87.2$ & $84.7-90.6$ \\
\hline TbLCYnB (2) & $85.3-86.5$ & $87.7-90.6$ \\
\hline CroYVMB (8) & $59.7-62.4$ & $51.6-57.6$ \\
\hline AYLCB (8) & $55.0-57.0$ & $52.8-63.5$ \\
\hline TYLCCNB (29) & $57.0-59.6$ & $39.8-66.1$ \\
\hline CLCuMB (4) & $50.3-50.6$ & $28.6-29.6$ \\
\hline RaLCuB (6) & $65.3-67.0$ & $34.7-72.8$ \\
\hline
\end{tabular}

*Numbers of sequences from the databases used in the comparisons.

\#The species are indicated as Tomato leaf curl betasatellite (ToLCB), Tobacco curly shoot betasatellite (TbCSB), Tomato yellow leaf curl Thailand betasatellite (TYLCTHB), Tobacco leaf curl Yunnan betasatellite (TbLCYnB), Croton yellow vein mosaic betasatellite (CroYVMB), Ageratum yellow vein Sri Lanka betasatellite (AYLCB), Tomato yellow leaf curl China betasatellite (TYLCCNB), Cotton leaf cur Multan betasatellite (CLCUMB), Radish leaf curl betasatellite (RaLCuB). For each column, the highest value is underlined.

Table 3: Percentages of nucleotide or amino acid sequence identities of betasatellite associated TbCSV-FB01 infecting common bean with betasatellites, associated with other begomoviruses.

of non-tree-like evolution, such as those expected in the presence of recombination (Figure 5). Based on this information, the sequences for break point analysis were subjected to know the recombination sites in virus isolate-FB01, using RDP3 with default settings [27]. Analyses showed that isolate is a recombinant and the DNA fragments might probably descended from TbCSV, MYMV, ToLCJoV, TbLCYnV and AEV like ancestors (Figure 6, Table 4). However, it is a derivative of known virus. Further, the analyses of satellite molecules showed betasatellite possess a hybrid genome of CroYVMB and TYLCCNB.

\section{Mechanical transmission of TbCSV}

Total one hundred of common bean cv. Arka komal was inoculated mechanically at two leaf stage. Out of these 80 plants expressed curly shoot, veins thickening and galling with dark green colour symptoms, with a minimum incubation period of 15-17 days. Later, the infected leaves become downward curled resulting in curly shoot appearance, similar to those observed on the field infected plants (Figure 7).

\section{Virus-vector relationship}

The relationship of virus-vector was characterized. Transmission efficiency of $100 \%$ was achieved on susceptible common bean cv. Arka komal plants. A minimum of eight whiteflies per plants was found to be effective for disease transmission (20\%), with a minimum incubation

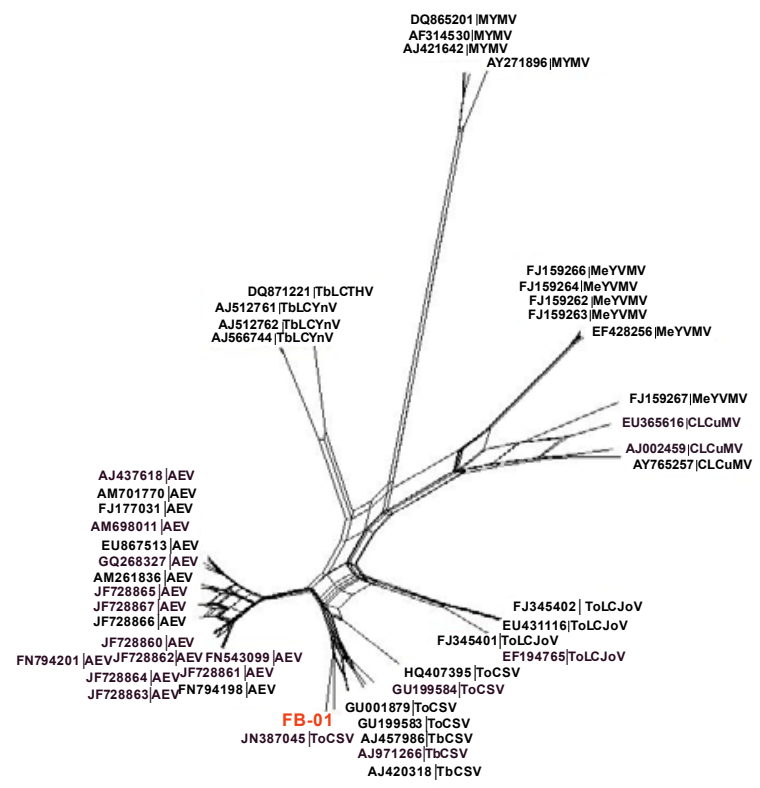

Figure 5: Neighbor-Net generated for the complete genome of TbCSV-FB01 with other begomoviruses has shown significant signals for phylogenetic conflict, indicating as recombinant virus.

period of 10-15 days to produce typical symptoms, under controlled conditions (Table 5).

The adult whiteflies required a minimum of $8 \mathrm{hrs}$ acquisition access period to acquire the virus from infected common bean cv. Arka komal plant, and effectively vectored with transmission efficiency of $20 \%$. However, there is increase in the transmission efficiency with the increase in acquisition access period, from $8 \mathrm{hr}$ to $24 \mathrm{hr}$ (Table 6). The control plants inoculated with non-viruliferous whiteflies did not show any symptoms, ruling out the contamination of whitefly culture. The minimum IAP was found to be $8 \mathrm{hrs}$ with transmission efficiency of $20 \%$, and there is increase in transmission efficiency, with the increase in inoculation access period from $8 \mathrm{hr}$ to $24 \mathrm{hr}$ (Table 6).

\section{Seed transmission}

Seed transmission of virus was studied by planting 100 seeds, each collected from infected and healthy common bean cv. Arka komal plants grown in controlled condition. The result revealed that the virus was not seed borne in nature. None of the plants, emerged from seeds collected from diseased plants, produced symptoms, even up to 40 days 
Citation: Venkataravanappa V, Swarnalatha P, Lakshminarayana Reddy CN, Mahesh B, Rai AB, et al. (2012) Molecular Evidence for Association of Tobacco Curly Shoot Virus and a Betasatellite with Curly Shoot Disease of Common Bean (Phaseolus vulgaris L.) from India. J Plant Pathol Microb 3:148. doi:10.4172/2157-7471.1000148

Page 6 of 9

\begin{tabular}{|c|c|c|c|c|c|c|c|c|c|}
\hline Component & $\begin{array}{l}\text { Break point } \\
\text { begin-end }\end{array}$ & Major Parent & Minor parent & RDP & GENECOV & Max Chi & Chimera & Si Scan & 3 Seq \\
\hline $\begin{array}{l}\text { Homologous } \\
\text { DNA-A }\end{array}$ & $\begin{array}{l}20-76 \\
2314-19 \\
129-1161 \\
531-1158 \\
1543-2313\end{array}$ & $\begin{array}{l}\text { TbCSV-[IN:SF1:10] } \\
\text { [HQ407395] } \\
\text { MYMV-[IN:Har:01] [AY271896] } \\
\text { ToLCJoV-[India:Pon:Kenaf:07] } \\
\text { [FJ345402] } \\
\text { TbLCYnV-[CN:Yn161:Tom:03] } \\
\text { [AJ566744] } \\
\text { AEV-[IN:HP:09] [FN543099] }\end{array}$ & $\begin{array}{l}\text { TbLCTHV-[TH:06] [DQ871221] } \\
\text { AEV-[PK:Turnip:07] [AM701770] } \\
\text { TbCSV-[IN:ND:Tom:11] [JN387045] } \\
\text { AEV-[PK:Turnip:07] [AM701770] } \\
\text { TbLCYnV-[CN:Yn136:02] } \\
\text { [AJ512761] }\end{array}$ & $\begin{array}{l}2.826 \times 10^{-5} \\
1.496 \times 10^{-6} \\
\text { NS } \\
2.497 \times 10^{-17} \\
\text { NS }\end{array}$ & $\begin{array}{l}4.817 \times 10^{-5} \\
\text { NS } \\
4.03 \times 10^{-2} \\
9.751 \times 10^{-24} \\
3.833 \times 10^{-3}\end{array}$ & $\begin{array}{l}8.374 \times 10^{-3} \\
\text { NS } \\
\text { NS } \\
9.369 \times 10^{-2} \\
1.224 \times 10^{-2}\end{array}$ & $\begin{array}{l}\text { NS } \\
\text { NS } \\
\text { NS } \\
9.875 \times 10^{-9} \\
\text { NS }\end{array}$ & $\begin{array}{l}\text { NS } \\
1.898 \times 10^{-3} \\
\text { NS } \\
8.197 \times 10^{-37} \\
9.819 \times 10^{-9}\end{array}$ & $\begin{array}{l}1.588 \times 10^{-2} \\
8.054 \times 10^{-5} \\
1.34 \times 10^{-3} \\
2.467 \times 10^{-9} \\
1.812 \times 10^{-2}\end{array}$ \\
\hline Betasatellite & $119-307$ & $\begin{array}{l}\text { CroYVMB-[IN:Luc:08] } \\
\text { EU604296 }\end{array}$ & $\begin{array}{l}\text { TYLCCNB-[CN:Y281:08] } \\
\text { AM980512 }\end{array}$ & NS & NS & $4.309 \times 10^{-2}$ & $9.999 \times 10^{-1}$ & NS & NS \\
\hline
\end{tabular}

NS-Non significance

Table 4: Breakpoint analysis of TbCSV-FB01and associated betasatellite, with their putative parental sequences.
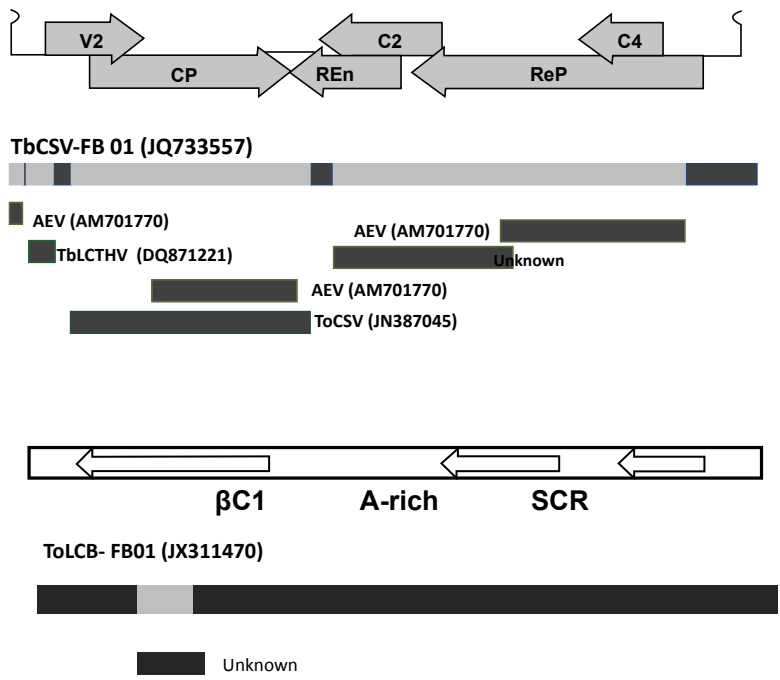

Figure 6: Analysis of recombination for complete genome of TbCSV FB01 and associated betasatellite isolated from common bean plant. The Begomoviruses and betasatllites acronyms given are Tobacco curly shoot virus (TbCSV), Ageratum enation virus (AEV), Tobacco leaf curl Thailand virus (TbLCTHV) and Tomato leaf curl betasateliite (ToLCB). Sequence of indeterminate origin is indicated as "unknown". The box below at the top of the diagram indicates the approximate position recombination is occurring in the genome of the begomoviruses.

after emergence. But, germination of seed from diseased plants was lower $(75 \%)$ compared to seeds from healthy plants (90\%).

\section{Discussion}

Geminiviruses are considered to be the most important viral pathogens in various food crops in the tropics and sub-tropics [32]. In India, Begomoviruses impose particularly serious constraints on the production of common bean. Despite concerted efforts to control certain geminiviruses and their vectors, there is appearance of frequent disease epidemics caused by newly emerging or re-emerging Geminiviruses, even in regions where such diseases were not prevalent earlier [33]. Over the past decade, epidemics caused by Begomoviruses have been attributed to various factors like change in climate, as well as occurrence of highly virulant whitefly vector biotype complexes which might likely enabled, both transmission of indigenous begomoviruses to new cultivated hosts, and the emergence of new recombinant virus variants [34]. The Begomoviruses are known to induce a range of symptoms such as leaf curling, yellow vein and leaf distortion in the plants they infect and cause diseases frequently $[35,36]$. The pulses are highly susceptible to yellow mosaic diseases caused by four different Begmoviruses [11]. In the present study, for the first time, Tobacco curly shoot virus causing curly shoot disease in common bean was characterized based on molecular characteristics, phylogenetic relationship and transmission studies from India, which is provisionally designated as Tobacco curly shoot virus [IN: Varanasi: common bean], based on the guidelines proposed by ICTV Geminivirus Study Group [2].

The TbCSV was first identified in tobacco in China [37], and subsequently in pepper [38], and ornamental plants [39]. No reports are available pertaining to TbCSV infecting beans in India. However, only two virus sequences isolated from tomato (GenBank Acc.No.JN387045) and sunflower (GenBank Acc.No. HQ407395) from north India are available in the databases. The nucleotide identities and phylogenetic relationship indicated the virus is very closely associated with TbCSV infecting solanaceous crops, sunflower and ageratum weeds in India and china. The Begomoviruses originating from the same geographical area, even though infecting different host plants, are more likely to be closely related than viruses infecting the same host and with different geographical areas [40]. The TbCSV not only infects cultivated crops (tobacco, tomato, pepper \& sunflower), but it also infects other weed plants such as ageratum (GenBank Acc. No. AJ971266). The weeds or wild, uncultivated plant species are commonly infected with viruses, and may act as sinks for diverse virus disease complexes [41], which spread to other cultivated plants subsequently [42]. In North eastern parts of India, especially Varanasi region, the spread of TbCSV in beans may be attributed firstly to growing of it in the adjacent fields of tomato. Secondly, large scale growing of tobacco in the adjacent state Bihar infected with both leaf curl and curly shoot virus. Thirdly, movement of viruliferous whiteflies between tobacco, tomato and bean fields during hot and dry season.

The betasatellite closely related to ToLCB is associated with the virus in the current study. The betasatellite have single Open Reading Frame (ORF) in the $\mathrm{C} 1$ gene. Start position on the $\mathrm{C} 1 \mathrm{ORF}$ was similar to other beta molecules, which potentially encodes a protein of 118 amino acids, which is extremely conserved in position and length [43]. The $\beta C 1$ ORF has the capacity to encode a $12.98 \mathrm{kDa}$ protein, comprising 118 amino acids fully functional in their respective hosts $[6,43,44]$. In India, both monopartite and bipartite Begomoviruses are causing many diseases in crop plants, and have been found with associated betasatellite [45]. The phylogenetic analysis of full-length sequence of betasatellite showed close clustering of the betasatellite associated with the ToLCB, indicating the possible spread of the betasatellite across geographical regions from solanaceous crops to legumes. Available evidence indicates that betasatellite does not contain iteron sequences of their helper viruses, yet they still depend on DNA-A for their replication $[5,6,46,47]$.

The DNA-A component alone is infective in TbCSV and betasatellite is not necessary for infection, but intensification of symptoms in a hostdependent manner has been well proved through agro-inoculation 
Citation: Venkataravanappa V, Swarnalatha P, Lakshminarayana Reddy CN, Mahesh B, Rai AB, et al. (2012) Molecular Evidence for Association of Tobacco Curly Shoot Virus and a Betasatellite with Curly Shoot Disease of Common Bean (Phaseolus vulgaris L.) from India. J Plant Pathol Microb 3:148. doi:10.4172/2157-7471.1000148
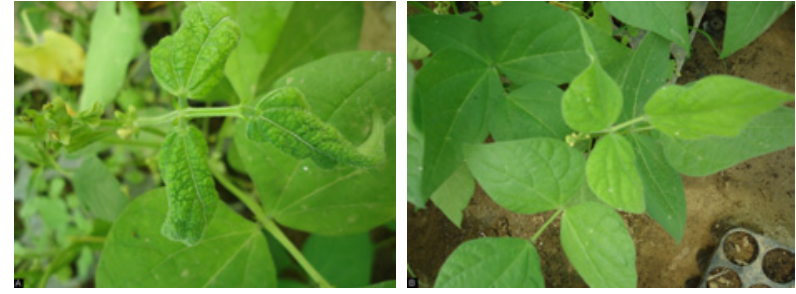

Figure 7: Common bean (cv. Arka komal) plant showing curly shoot symptoms (A), 16 days after mechanical sap inoculation with TbCSV-FB01 isolate. Bean plant without symptoms $(B)$ inoculated without virus, used as negative control in the experiment.

\begin{tabular}{|l|l|l|}
\hline $\begin{array}{l}\text { Number of whiteflies } \\
\text { Per Plant }\end{array}$ & $\begin{array}{l}\text { No. of plants Infected/ } \\
\text { Inoculated }\end{array}$ & $\begin{array}{l}\text { Transmission } \\
(\%)\end{array}$ \\
\hline 0 & $0 / 10$ & 0 \\
\hline 1 & $0 / 10$ & 0 \\
\hline 2 & $0 / 10$ & 0 \\
\hline 4 & $0 / 10$ & 0 \\
\hline 6 & $0 / 10$ & 0 \\
\hline 8 & $2 / 10$ & 20 \\
\hline 10 & $4 / 10$ & 40 \\
\hline 12 & $4 / 10$ & 60 \\
\hline 14 & $8 / 10$ & 80 \\
\hline 20 & $10 / 10$ & 100 \\
\hline
\end{tabular}

Table 5: Transmission efficiency of TbSCV-FB01 by Bemisia tabaci.

\begin{tabular}{|c|c|c|c|c|c|c|c|}
\hline \multicolumn{4}{|c|}{ Determination of minimum AAP* } & \multicolumn{4}{|c|}{ Determination of minimum IAP\# } \\
\hline \multirow[t]{2}{*}{$\mathrm{AAP}^{*}$} & \multirow[t]{2}{*}{ IAP\# } & \multicolumn{2}{|c|}{ Transmission } & \multirow[t]{2}{*}{ AAP $^{*}$} & \multirow[t]{2}{*}{ IAP\# } & \multicolumn{2}{|c|}{ Transmission } \\
\hline & & $\begin{array}{l}\text { (plants } \\
\text { infected/ } \\
\text { plants } \\
\text { inoculated) }\end{array}$ & $\begin{array}{l}\text { Percentage } \\
\text { of plants } \\
\text { infected }\end{array}$ & & & $\begin{array}{l}\text { (plants } \\
\text { infected/ } \\
\text { plants } \\
\text { inoculated) }\end{array}$ & $\begin{array}{l}\text { Percentage } \\
\text { of plants } \\
\text { infected }\end{array}$ \\
\hline $0 \mathrm{~min}$ & \multirow[t]{13}{*}{$12 \mathrm{hrs}$} & 0/10 & 0 & \multirow[t]{13}{*}{$12 \mathrm{hr}$} & $0 \min$ & $0 / 10$ & 0 \\
\hline $5 \mathrm{~min}$ & & 0/10 & 0 & & $5 \mathrm{~min}$ & $0 / 10$ & 0 \\
\hline $10 \mathrm{~min}$ & & $0 / 10$ & 0 & & $10 \mathrm{~min}$ & 0/10 & 0 \\
\hline $15 \mathrm{~min}$ & & $0 / 10$ & 0 & & $15 \min$ & 0/10 & 0 \\
\hline $20 \mathrm{~min}$ & & 0/10 & 0 & & $20 \mathrm{~min}$ & 0/10 & 0 \\
\hline $30 \mathrm{~min}$ & & $0 / 10$ & 0 & & $30 \mathrm{~min}$ & $0 / 10$ & 0 \\
\hline $1 \mathrm{hrs}$ & & $0 / 10$ & 0 & & $1 \mathrm{hr}$ & $0 / 10$ & 0 \\
\hline $4 \mathrm{hrs}$ & & 0/10 & 0 & & $4 \mathrm{hrs}$ & $0 / 10$ & 0 \\
\hline $8 \mathrm{hrs}$ & & $2 / 10$ & 20 & & $8 \mathrm{hrs}$ & 2/10 & 20 \\
\hline 10hrs & & $5 / 10$ & 50 & & 10hrs & $5 / 10$ & 50 \\
\hline $12 \mathrm{hrs}$ & & $8 / 10$ & 80 & & $12 \mathrm{hrs}$ & $8 / 10$ & 80 \\
\hline $16 \mathrm{hrs}$ & & 9/10 & 90 & & $16 \mathrm{hrs}$ & $9 / 10$ & 90 \\
\hline $24 \mathrm{hrs}$ & & $10 / 10$ & 100 & & $24 \mathrm{hrs}$ & $10 / 10$ & 100 \\
\hline
\end{tabular}

*Acquisition access period

\#Inoculation access period

Table 6: Determination of minimum acquisition access period and minimum in oculation access period for insect transmission of TbSCV-FB01, to common bean plants.

$[48,49]$. In the present, the betasatellite associated with TbCSV infecting common bean showed more identity with ToLCB, rather than TbCSB. Further, phylogeny showed close clustering of TbCSB, characterized with ToLCB reported from Nepal than India. This indicates the transreplication of betasatellite in common bean plants in the presence of TbCSV. Similarly, previous report showed that trans-replication of betasatellites in plants inoculated with TYLCCV and TbCSV has been well proved through agro-inoculation [50]. Further, yellow vein mosaic disease of pumpkin was caused by Tomato leaf curl Palampur virus, is associated with Pepper leaf curl betasatellite [51], and in cotton, single betasatellite molecule will support for pathogenicity of multiple viruses [10].

Recombination plays major role for the emergence of new viruses [30]. However, results obtained from comparisons of different parts of the viral genome of TbCSV revealed substantial differences in their place in the tree (data not shown). These results suggested that TbCSV possess a hybrid genome of TbCSV, MYMV, ToLCJoV, TbLCYnV and AEV, and betasatellite from CroYVMB and TYLCCNB like ancestors. These data provide evidence for the significant contribution of recombination, for emergence of novel Begomovirus, adding to the genetic diversification and its population structures in India.

Many reports are available worldwide; the Begomoviruses are mechanically transmissible only to $N$. benthamiana plants. However, a few reports such as Bean dwarf mosaic virus [52], Bean golden mosaic virus [53], Pepper golden mosaic virus [54] and Watermelon curly mottle virus (WCMoV) [55] were shown to be mechanically transmissible to their original, and/or other host plants. In bean plants, the Bean dwarf mosaic virus was sap-transmitted up to $100 \%$, the mechanical transmission rate of ToLCNDV in oriental melon and potato is more than $93 \%[56,57]$. The virus isolate in the present study was readily sap transmissible to common bean with $80 \%$ transmission efficiency. Similarly, the Begomovirus in the present study was successfully transmitted by whitefly, in accordance with other Begomoviruses known to date [58].

This is the first report of Begomovirus associated with betasatellite causing curly shoot disease of common bean. Further, the betasatellite reported here is distinct from other known Geminivirus components. In conclusion, the virus associated with curly shoot disease of common bean is a newly emerged variant of TbCSV moved to economically important new host and posing severe constraint on grain legumes production in India.

\section{Acknowledgements}

The authors are grateful to the Director, Indian Institute of Vegetable Research, Varanasi, for providing research facilities and his keen interest in this study.

\section{References}

1. Lefeuvre P, Harkins GW, Lett JM, Briddon RW, Chase MW, et al. (2011) Evolutionary time-scale of the begomoviruses: evidence from integrated sequences in the Nicotiana genome. PLoS One 6: e19193.

2. Fauquet CM, Briddon RW, Brown JK, Moriones E, Stanley J, et al. (2008) Geminivirus strain demarcation and nomenclature. Arch Virol 153: 783-821.

3. Hanley-Bowdoin L, Settlage SB, Orozco BM, Nagar S, Robertson D (2000) Geminiviruses: models for plant DNA replication, transcription, and cell cycle regulation. Crit Rev Biochem Mol Biol 35: 105-140.

4. Sharma P, Rishi N, Malathi VG (2005) Molecular cloning of coat protein gene of an Indian Cotton Leaf Curl Virus (CLCuV-HS2) isolate and its phylogenetic relationship with others members of Geminiviridae. Virus Genes 30: 85-91.

5. Saunders K, Bedford ID, Briddon RW, Markham PG, Wong SM, et al. (2000) A unique virus complex causes Ageratum yellow vein disease. PNAS 97: 68906895.

6. Briddon RW, Mansoor S, Bedford ID, Pinner MS, Saunders K, et al. (2001) Identification of DNA components required for induction of cotton leaf cur disease. Virology 285: 234-243.

7. Briddon RW, Bull SE, Amin I, Idris AM, Mansoor S, et al. (2003) Diversity of DNA beta, a satellite molecule associated with some monopartite begomoviruses. Virology 312: 106-121.

8. Nawaz-ul-Rehman MS, Fauquet CM (2009) Evolution of geminiviruses and their satellites. FEBS Lett 583: 1825-1832.

9. Briddon RW, Bull SE, Amin I, Mansoor S, Bedford ID, et al. (2004) Diversity of 
Citation: Venkataravanappa V, Swarnalatha P, Lakshminarayana Reddy CN, Mahesh B, Rai AB, et al. (2012) Molecular Evidence for Association of Tobacco Curly Shoot Virus and a Betasatellite with Curly Shoot Disease of Common Bean (Phaseolus vulgaris L.) from India. J Plant Pathol Microb 3:148. doi:10.4172/2157-7471.1000148

DNA 1: a satellite-like molecule associated with monopartite begomovirus-DNA beta complexes. Virology 324: 462-474.

10. Mansoor S, Briddon RW, Bull SE, Bedford ID, Bashir A, et al. (2003) Cotton lea curl disease is associated with multiple monopartite begomoviruses supported by single DNA beta. Arch Virol 148: 1969-1986.

11. Qazi J, llyas M, Mansoor S, Briddon RW (2007) Legume yellow mosaic viruses: genetically isolated begomoviruses. Mol Plant Pathol 8: 343-348.

12. Capoor SP, Varma PM (1950) A new virus disease of Dolichos lablab. Curr Sci 19: $248-249$

13. Nariani TK (1960) Yellow mosaic of mung (Phaseolus aureus L.). Indian Phytopathology 13: 24-29.

14. Williams FJ, Grewal JS, Amin KS (1968) Serious and new diseases of pulse crops in India in 1966. Plant Disease Reporter 52: 300-304

15. Singh RN (1979) Natural infection of bean (Phaseolus vulgaris) by mung bean yellow mosaic virus. J Mycol Plant Pathol 9: 124-126.

16. Muniyappa V, Rajeshwari R, Bharathan N, Reddy DVR, Nolt BL (1987) Isolation and characterization of a geminivirus causing yellow mosaic disease of Horsegram (Macrotyloma uniflorum (Lam.) Verdc.) in India. Journal of Phytopathology 119: 81-87.

17. Maruthi MN, Manjunatha B, Rekha AR, Govindappa MR, Colvin J, et al (2006) Dolichos yellow mosaic virus belongs to a distinct lineage of Old World begomoviruses; its biological and molecular properties. Ann Appl Biol 149: 187 195.

18. Ilyas M, Qazi J, Mansoor S, Briddon RW (2009) Molecular characterisation and infectivity of a "Legumovirus" (genus Begomovirus: family Geminiviridae) infecting the leguminous weed Rhynchosia minima in Pakistan. Virus Res 145 279-284

19. Doyle JJ, Doyle JL (1990) Isolation of plant DNA from fresh tissue. Focus 12 13-15

20. Venkataravanappa V, Lakshminarayana Reddy CN, Jalali S, Krishna Reddy M (2012) Molecular characterization of distinct bipartite begomovirus infecting bhendi (Abelmoschus esculentus L.) in India. Virus Genes 44: 522-535.

21. Rojas MR, Gilbertson RL, Russell DR, Maxwell DP (1993) Use of degenerate primers in the polymerase chain reaction to detect whitefly-transmitted geminiviruses. Plant Dis 77: 340-347.

22. Briddon RW, Bull SE, Mansoor S, Amin I, Markham PG (2002) Universal primers for the PCR-mediated amplification of DNA beta: a molecule associated with some monopartite begomoviruses. Mol Biotechnol 20: 315-318

23. Hall TA (1999) BioEdit: a user-friendly biological sequence alignment editor and analysis program for Windows 95/98/NT. Nucleic Acids Symp Ser 41: 95-98.

24. Thompson JD, Higgins DG, Gibson TJ (1994) CLUSTAL W: improving the sensitivity of progressive multiple sequence alignment through sequence weighting, position-specific gap penalties and weight matrix choice. Nucleic Acids Res 22: 4673-4680.

25. Tamura K, Peterson D, Peterson N, Stecher G, Nei M, et al. (2011) MEGA5 molecular evolutionary genetics analysis using maximum likelihood, evolutionary distance, and maximum parsimony methods. Mol Biol Evol 28: 2731-2739.

26. Huson DH, Bryant D (2006) Application of phylogenetic networks in evolutionary studies. Mol Biol Evol 23: 254-267.

27. Martin DP, Lemey P, Lott M, Moulton V, Posada D, et al. (2010) RDP3: a flexible and fast computer program for analyzing recombination. Bioinformatics 26 : 2462-2463

28. Heyraud F, Matzeit V, Kammann M, Schaefer S, Schell J, et al. (1993) Identification of the initiation sequence for viral-strand DNA synthesis of wheat dwarf virus. EMBO J 12: 4445-4452.

29. Briddon RW, Brown JK, Moriones E, Stanley J, Zerbini M, et al. (2008) Recommendations for the classification and nomenclature of the DNA-beta satellites of begomoviruses. Arch Virol 153: 763-781.

30. Padidam M, Sawyer S, Fauquet CM (1999) Possible emergence of new geminiviruses by frequent recombination. Virology 265: 218-225.

31. Sanz Al, Fraile A, Garcia-Arenal F, Zhou X, Robinson DJ, et al. (2000) Multiple infection, recombination and genome relationships among begomovirus isolates found in cotton and other plants in Pakistan. J Gen Virol 81: 1839-1849.

32. Boulton M (2003) Geminiviruses: major threats to world agriculture. Ann App Biol 142: 143

33. Varma A, Malathi VG (2003) Emerging geminivirus problems: A serious threat to crop production. Ann Appl Biol 142: 145-164.

34. Albuquerque LC, Martin DP, Avila AC, Inoue-Nagata AK (2010) Characterization of tomato yellow vein streak virus, a begomovirus from Brazil. Virus Genes 40 140-147.

35. Wang X, Xie Y, Zhou X (2004) Virus Genes 29: 303-309.

36. Seal SE, VandenBosch F, Jeger MJ (2006) Factors influencing Begomovirus evolution and their increasing global significance: implications for sustainable control. Crit Rev Plant Sci 25: 23-46.

37. Xie Y, Zhou X, Zhang Z, Qi Y (2002) Tobacco curly shoot virus isolated in Yunnan is a distinct species of Begomovirus. Chin Sci Bull 47: 199-201.

38. Qing L, Xiong Y, Sun XC, Yang SY (2010) First report of tobacco curly shoot virus infecting pepper in China. Plant Dis 94: 637.

39. Khan AA, Naqvi QA, Khan MS, Singh R, Raj SK (2005) First report of a begomovirus infecting Calendula in India. Plant Pathol 54: 569.

40. Harrison B, Robinson D (1999) Natural genomic and antigenic variation in whitefly-transmitted geminiviruses (begomoviruses). Annu Rev Phytopathol 37 369-398.

41. Leke WN, Brown JK, Ligthart ME, Sattar N, Njualem DK, et al. (2012) Ageratum conyzoides: a host to a unique begomovirus disease complex in Cameroon. Virus Res 163: 229-237.

42. Jones RA (2009) Plant virus emergence and evolution: origins, new encounter scenarios, factors driving emergence, effects of changing world conditions, and prospects for control. Virus Res 141: 113-130.

43. Zhou X, Liu Y, Calvert L, Munoz C, Otim-Nape GW, et al. (1997) Evidence that DNA-A of a geminivirus associated with severe cassava mosaic disease in Uganda has arisen by interspecific recombination. J Gen Virol 78: 2101-2111.

44. Venkataravanappa V, Reddy CN, Swaranalatha P, Jalali S, Briddon RW, et al (2011) Diversity and phylogeography of begomovirus-associated beta satellites of okra in India. Virol J 8: 555

45. Sivalingam PN, Malathi VG, Varma A (2010) Molecular diversity of the DNA beta satellites associated with tomato leaf curl disease in India. Arch Virol 155 757-764.

46. Kon T, Hidayat SH, Hase S, Takahashi H, Ikegami M (2006) The natura occurrence of two distinct begomoviruses associated with DNA $\beta$ and a recombinant DNA in a tomato plant from Indonesia. Phytopathology 96: 517 525.

47. Kon T, Kuwabara K, Hidayat SH, Ikegami M (2007) A begomovirus associated with Ageratum yellow vein disease in Indonesia: evidence for natural recombination between tomato leaf curl Java virus and Ageratum yellow vein virus-[Java]. Arch Virol 152: 1147-1157.

48. Li Z, Xie Y, Zhou X (2005) Tobacco curly shoot virus DNA 3 is not necessary for infection but intensifies symptoms in a host-dependent manner. Phytopathology 95: 902-908.

49. Qian Y, Tan Z, Liu Y, Briddon RW, Zhou X (2008) Size reversion of a truncated DNA $\beta$ associated with Tobacco curly shoot virus. Virus Res 131: 288-292.

50. Qing L, Zhou X (2009) Trans-replication of, and competition between, DNA beta satellites in plants inoculated with Tomato yellow leaf curl China virus and Tobacco curly shoot virus. Phytopathology 99: 716-720.

51. Namrata J, Saritha RK, Datta D, Singh M, Dubey RS, et al. (2010) Molecular Characterization of Tomato leaf curl Palampur virus and Pepper leaf cur betasatellite naturally infecting pumpkin (Cucurbita moschata) in India. Indian J Virol 21: 128-132.

52. Morales F, Niessen A, Ramirez B, Castano M (1990) Isolation and partia characterization of a geminivirus causing bean dwarf mosaic. Phytopathology 80: 96-101.

53. Gilbertson RL, Hidayat SH, Martinez RT, Leong SA, Faria JC, et al. (1991) 
Citation: Venkataravanappa V, Swarnalatha P, Lakshminarayana Reddy CN, Mahesh B, Rai AB, et al. (2012) Molecular Evidence for Association of Tobacco Curly Shoot Virus and a Betasatellite with Curly Shoot Disease of Common Bean (Phaseolus vulgaris L.) from India. J Plant Pathol Microb 3:148. doi:10.4172/2157-7471.1000148

Page 9 of 9

Differentiation of bean-infecting geminiviruses by nucleic acid hybridization probes and aspects of bean golden mosaic in Brazil. Plant Dis 75: 336-342.

54. Stenger DC, Duffus JE, Villalon B (1990) Biological and genomic properties of a geminivirus isolated from pepper. Phytopathology 80: 704-709.

55. Brown JK, Nelson MR (1986) Whitefly-borne viruses of melons and lettuce in Arizona. Phytopathology 76: 236-239.

56. Chang HH, Ku HM, Tsai WS, Chien RC, Jan FJ (2010) Identification and characterization of a mechanical transmissible begomovirus causing leaf cur on oriental melon. Eur J Plant Pathol 127: 219-228.

57. Usharani KS, Surendranath B, Paul-Khurana SM, Garg ID, Malathi VG (2004) Potato leaf curl-a new disease of potato in northern India caused by a strain of tomato leaf curl New Delhi virus. Plant Pathol 53: 235.

58. Briddon RW, Pinner MS, Stanley J, Markham PG (1990) Geminivirus coat protein gene replacement alters insect specificity. Virology 177: 85-94. 